\title{
Lychnorhiza Iucerna Haeckel (Scyphozoa, Rhizostomeae) and Libinia ferreirae Brito Capello (Decapoda, Majidae) association in southern Brazil ${ }^{1}$
}

\author{
Miodeli Nogueira Júnior ${ }^{2} \&$ Maria A. Haddad ${ }^{2}$ \\ 1 Contribution number 1606 of the Departamento de Zoologia, Universidade Federal do Paraná. \\ ${ }^{2}$ Departamento de Zoologia, Universidade Federal do Paraná. Caixa Postal 19020, 81531-980 Curitiba, Paraná, Brasil. \\ E-mail: miodeli@gmail.com, mahaddad@ufpr.br
}

\begin{abstract}
Associations between jellyfish and other organisms are frequently reported. Neverhteless, few of those records include crabs inhabiting medusae. Lychnorhiza lucerna Haeckel, 1888 were sampled $(\mathrm{n}=1988)$ on the coast of the State of Paraná $\left(25^{\circ} 20^{\prime}-25^{\circ} 55^{\prime} \mathrm{S}, 48^{\circ} 10^{\prime}-48^{\circ} 35^{\prime} \mathrm{W}\right)$, southern Brazil, from December 1997 to December 2004. Eight percent (166 individuals) of the medusae had one spider crab Libinia ferreirae Brito Capello, 1871 living within its subgenital porticus or on the oral arms. Megalopal stages of the same crab were also found on three jellyfish. All crabs associated with $L$. lucerna were young and smaller $(<3 \mathrm{~cm})$ than solitary crabs caught on the bottom. Thus, $L$. ferreirae probably colonizes the jellyfish as a late larva and uses it as a floating nursery before becoming free-living on the ocean bottom as a typical adult crab.
\end{abstract}

KEY WORDS. Brachyura, Cnidaria, Crustacea, symbiosis.

RESUMO. Associação entre Lychnorhiza lucerna Haeckel (Scyphozoa, Rhizostomeae) e Libinia ferreirae Brito Capello (Decapoda, Majidae) no sul do Brasil. Associações entre medusas e diversos outros organismos são freqüentemente relatadas. Entretanto sobre caranguejos que vivem em águas-vivas apenas alguns registros foram encontrados. Entre dezembro de 1997 e dezembro de 2004, foram coletados 1988 exemplares de Lychnorhiza Iucerna Haeckel, 1888 na costa do Estado do Paraná $\left(25^{\circ} 20^{\prime}-25^{\circ} 55^{\prime} \mathrm{S}, 48^{\circ} 10^{\prime}-48^{\circ} 35^{\prime} \mathrm{W}\right)$, Sul do Brasil. Oito por cento (166 indivíduos) das medusas abrigavam um caranguejo aranha Libinia ferreirae Brito Capello, 1871 no interior de seu pórtico subgenital ou sobre seus braços orais. Megalopas da mesma espécie também foram encontradas em três exemplares de L. lucerna. Todos os caranguejos encontrados associados eram jovens e menores $(<3 \mathrm{~cm})$ do que os espécimes solitários capturados no fundo. Os resultados indicam que $L$. ferreirae coloniza a água-viva em sua fase pós-larval e a usa como um criadouro flutuante, antes de se estabelecer no fundo como um caranguejo adulto típico.

PALAVRAS CHAVE. Brachyura, Cnidaria, Crustacea, simbiose.

Various organisms may associate with jellyfish, like zooxanthellae, fishes, amphipods, cestodes, trematodes, cephalopods, barnacles and others (ArAI 1997). Associations between jellyfish and crabs are known only from few records (Tab. I). Extensive reviews, such as those of symbiotic relations of Crustacea (Ross 1983) or on the functional biology of the Scyphozoa (ARAI 1997) contain no information on such associations, and only FRANC (1994) briefly commented on the subject.

Benefits of these associations are not clearly understood. Medusa may serve as a simple means of transport, shelter and perhaps food for the crab (CoRRINGTON 1927, VAZ FERREIRA 1972) and, at least in some cases, crab dispersal may be greatly enhanced by the jellyfish (Graham 1989). Mucous, waste particles, jellyfish prey (CORRINGTON 1927) or tissues may serve as food for the crabs (Jachowski 1963, Shanks \& Graham 1988).
Apparently, the relationship between jellyfish and crabs differs depending on the species involved. In some cases crabs spend a considerable portion of their early development within medusae - from megalops to young crabs. Then, they fall to the ocean bottom and continue their life cycle (WЕYмоuтH 1910 apud Corrington 1927, Graham 1989). In other cases, the association seems transient with crabs entering for preying on medusae while they are near the ocean floor (PhilLips et al. 1969).

Information on these associations are scant because most of the records are based on punctual samples or short comments. Along the brazilian coast, only Moreira (1961) cited briefly the occurrence of Libinia ferreirae Brito Capello, 1871 associated with the Rhizostomeae Phyllorhiza punctata von Lendenfeld, 1884. Here, the available literature on jellyfish crab associations is revised (Tab. I) and novel data on 
Lychnorhiza lucerna Haeckel, 1888 and the spider crab L. ferreirae is described in coastal Paraná, southern Brazil, the first well documented record of this interaction.

\section{MATERIAL AND METHODS}

Jellyfish and crabs were collected with otter trawls at two sites on the coast of the state of Paraná, southern Brazil $\left(25^{\circ} 20^{\prime}\right.$ $\left.25^{\circ} 55^{\prime} \mathrm{S}, 48^{\circ} 10^{\prime}-48^{\circ} 35^{\prime} \mathrm{W}\right)$. Two samples at $30 \mathrm{~m}$ depth were taken near Currais Islands, $20-25 \mathrm{~km}$ offshore, in July and August of 1999 with nets of $3 \mathrm{~cm}$ mesh. The second site, on the shoreline at the city of Guaratuba, at 8-14 m depth, 1-4 km offshore, was sampled monthly, between April 2001 and March 2002 (with the exceptions of June and August), with $3 \mathrm{~cm}$ mesh and between February 2003 and December 2004 (with the exception of June 2003 and March 2004), with two simultaneous trawls, mesh sizes 1 and $2 \mathrm{~cm}$. Specimens were fixed in formalin $4 \%$ with seawater.

Width and height of genital ostia and the bell diameter of the medusa, carapace width (without spines) and length of the crabs were measured. Sex was determined in jellyfish by examination of gonadal tissue, and in crabs by abdominal morphology.

Spider crabs not associated with medusae were obtained from the 2003/2004 samples and by fishermen. All medusae species in the samples were identified following MAYER (1910) and Mianzan \& CoRnelius (1999) and crabs were identified following MeLo (1996).

\section{RESULTS}

In 1988 individuals of L. lucerna collected, 166 (8\%) had the spider crab L. ferreirae living within their genital porticus, clinging to their oral arms, or eventually on the exumbrela, always with only one crab per jellyfish. Megalops of $L$. ferreirae (identified following PoHLE et al. 1999) were found in three medusae, but is very probable that they were overlooked.

Range and average dimensions of the medusae umbrelar diameter and genital ostium height and width are shown in table II. The measurements of crabs collected inside or outside the medusae $(n=271)$ are in table III. The carapace width of the associated crabs was always less than the genital ostium width of its host and, conversely, carapace width of crabs on the outside was greater.

About $70 \%$ of the associated crabs were smaller than 15 $\mathrm{mm}$ (Fig. 1). All of them were young (Tab. III), frequently moulting and they showed no preference for the sex of the host jellyfish $\left(\chi^{2}=1.096, \mathrm{p}>0.05\right.$, Tab. II).

Of the 105 spider crabs collected on the outside of the medusae, 68 were males and 37 were females (of which 34 were spawning). Individuals found on the outside were larger than those on the inside (Mann-Whitney, $\mathrm{p}<0.01$, df $=270$, Fig. 2, Tab. III) and most of them were carrying several organisms on their carapace, such as algae, polychaetes, sea anemones, hydroids, barnacles, bryozoans, etc.

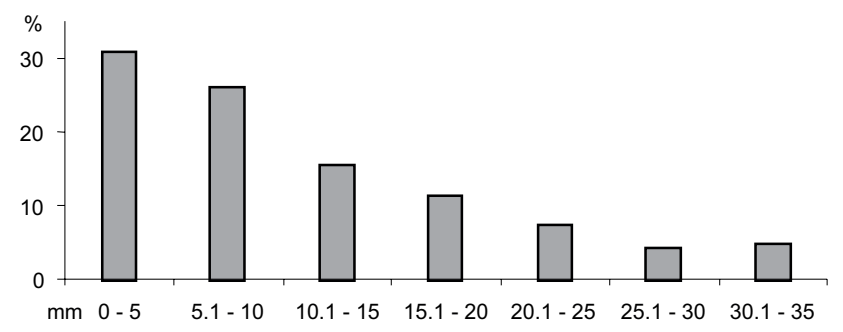

Figure 1 . Size class frequency $L$. ferreirae associated with $L$. lucerna $(n=166)$.

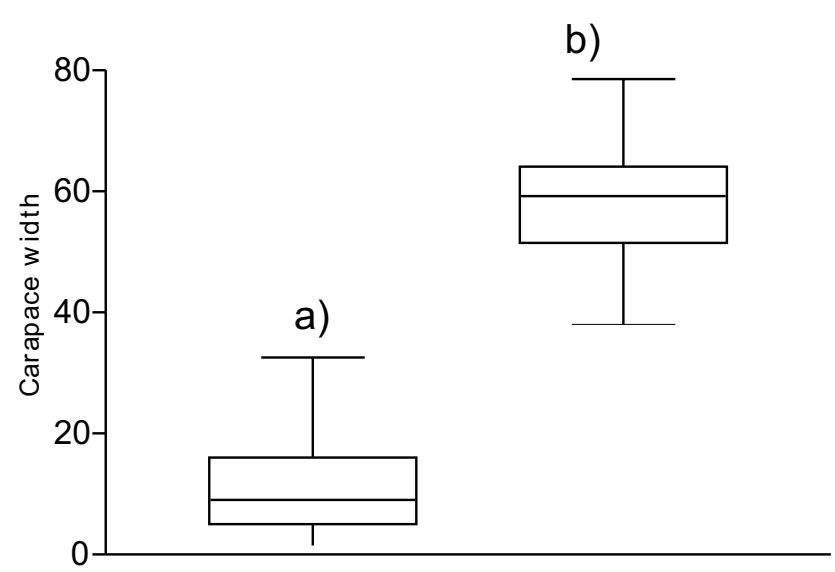

Figure 2. Comparison of Libinia ferreirae carapace width (in $\mathrm{mm}$ ), living inside (a) and outside (b) Lychnorhiza lucerna; $\mathrm{a}$ and $\mathrm{b}$ belong to different statistical populations, Mann-Whitnney, $\mathrm{p}<0.01, \mathrm{df}=$ 270. (-) Median; ( $\square$ ) 25-75\%; ( $T$ ) range.

Lychnorhiza lucerna size class distribution shows (Fig. 3) that about $80 \%$ of all medusae obtained in the area $(n=1988)$ had an umbrellar diameter less than $150 \mathrm{~mm}$. A greater frequency of crabs were associated with jellyfish bigger than 150 $\mathrm{mm}$ in diameter.

Carapace width of $L$. ferreirae was significantly correlated with the umbrellar diameter of L. lucerna (Spearman, $\mathrm{r}=0.83$, $\mathrm{p}<0.01, \mathrm{n}=166$, Fig. 4).

Seasonal variation in the association frequencies occurred during the four years studied (Fig. 5). High frequencies were found in the spring (September and October), with the exception of May 2001, when the greatest frequency was recorded (22.7\%).

Other scyphozoan and cubozoan medusae found in the samples were: Chiropsalmus quadrumanus (F.Müller, 1859) ( $\mathrm{n}=$ 545), Tamoya haplonema F. Müller, 1859 ( $\mathrm{n}=20)$; Chrysaora lactea Eschscholtz, $1829(\mathrm{n}=1553)$ and Phyllorhiza punctata von Lendenfeld, $1884(\mathrm{n}=50)$. Among them only one specimen of $P$. punctata was associated with the spider crab L. ferreirae. 


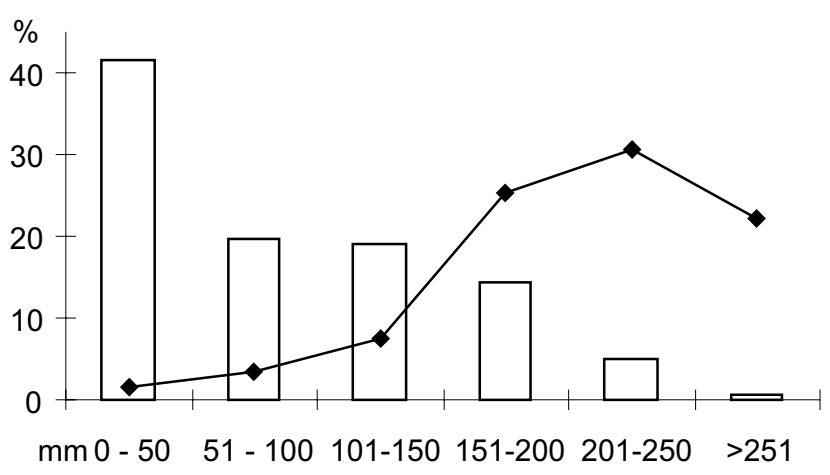

Figure 3. Size class frequency of the umbrelar diameter of $L$. lucerna and associated $L$. ferreirae frequencies. (Bars $=L$. lucerna frequencies, $\mathrm{n}=1988$; Line $=$ frequencies of $L$. ferreirae associated on each medusa's size class; $\mathrm{n}=166$ ).

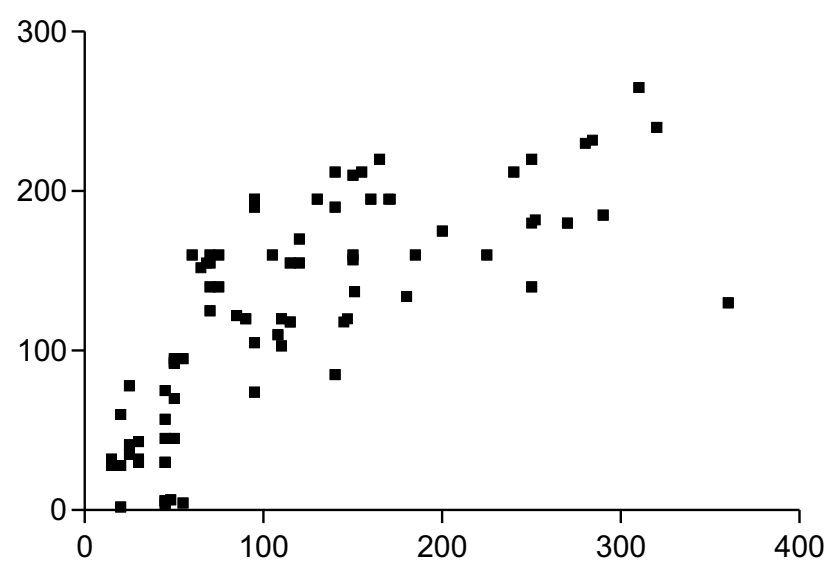

Figure 4. Dispersion graphic between the diameter of L. Iucerna ( $x$ ) and the carapace width of L. ferreirae (y) associated, in $\mathrm{mm}$. Both variables are significantly correlated (Spearman, $r=0.83, p<$ $0.01, \mathrm{n}=166$ ).

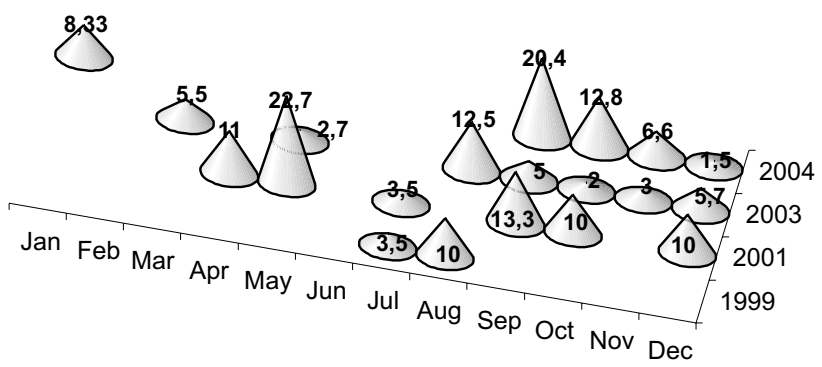

Figure 5. Temporal distribution of the frequency (\%) of the association between $L$. lucerna and $L$. ferreirae. Zero frequency, months and year without samples were omitted.

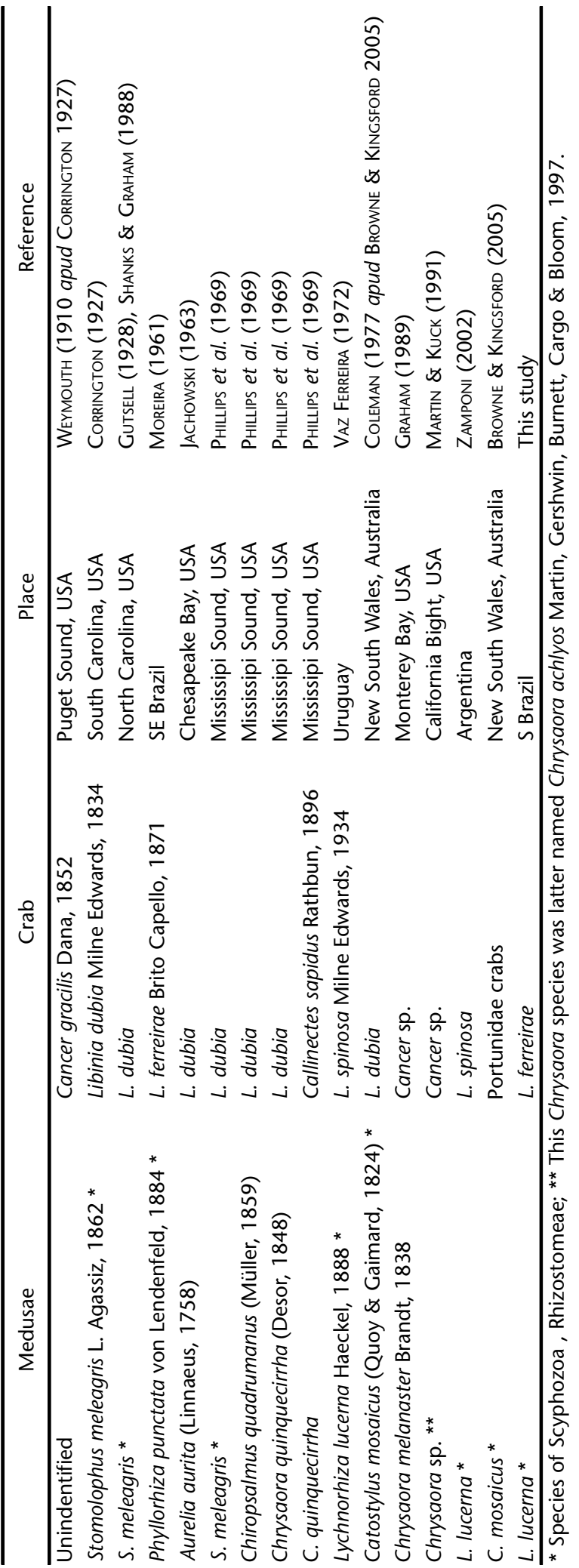


Table II. Summary of measurement data obtained for L. lucerna (in $\mathrm{mm}$ ).

\begin{tabular}{|c|c|c|c|c|c|c|c|c|c|c|}
\hline \multirow{2}{*}{ L. lucerna } & \multicolumn{2}{|c|}{ Umbrelar diameter } & \multicolumn{2}{|c|}{ Genital ostium height } & \multicolumn{2}{|c|}{ Genital ostium width } & \multicolumn{3}{|c|}{ Sex } & \multirow{2}{*}{ N } \\
\hline & Range & Mean & Range & Mean & Range & Mean & Young & Male & Female & \\
\hline Without crab & $12-330$ & 94.72 & \multicolumn{2}{|c|}{ Not measured } & \multicolumn{2}{|c|}{ Not measured } & \multicolumn{3}{|c|}{ Not analyzed } & 1822 \\
\hline With crab & $15-255$ & 113.06 & $4.3-25.0$ & 13.88 & $6.8-37.5$ & 23.29 & 50 & 55 & 61 & 166 \\
\hline
\end{tabular}

Table III. Summary of measurement data obtained for L. ferreirae (in $\mathrm{mm}$ ).

\begin{tabular}{|c|c|c|c|c|c|c|c|c|}
\hline \multirow{2}{*}{ L. ferreirae } & \multicolumn{2}{|c|}{ Carapace width } & \multicolumn{2}{|c|}{ Carapace length } & \multicolumn{3}{|c|}{ Sex } & \multirow{2}{*}{$\mathrm{N}$} \\
\hline & Range & Mean & Range & Mean & Young & Male & Female & \\
\hline Inside medusa & $1.5-36.2$ & 11,4 & $2-33$ & 10.11 & 166 & 0 & 0 & 166 \\
\hline Outside medusa & $39.8-72.5$ & 57.7 & $41.2-76.5$ & 61.30 & 0 & 68 & 37 & 105 \\
\hline
\end{tabular}

\section{DISCUSSION}

The frequency of the association of $L$. lucerna and $L$. ferreirae was low (8\%). Perhaps the number of associated crabs was influenced by the collecting methods. However we do not believe this to be the case. First, crabs in association are smaller than free-living crabs, with no size overlap between the two groups (Fig. 5). Second, free-living crabs were larger than the genital ostia of the medusa, which prevents them from entering the porticus. Third, the associated crabs had a strong tendency to grasp and remain on the jellyfish, even when these are stranded, holding tightly on its host by means of the sharp and strongly curved ends of their legs, or they hid within when perturbed. Finally, some crabs may have left the medusa when they were netted, causing an underestimation of the crabs in association. Thus, while $8 \%$ association seems small, it is apparently a common, adaptive association.

It is possible that the relative abundance of the two species explains the low rate of the association. While L. lucerna was one of the most common medusae at the study site, the spider crab was relatively rare in our samples. This may also explain why only one crab per medusa while other authors have found two (VAZ FERreira 1972, Zamponi 2002). However, it must be considered that if only medusae bigger than $150 \mathrm{~mm}$ is taken into account, the frequency is considerable higher (26.45\%).

The association of L. lucerna with another species of Libinia Leach, 1815 , L. spinosa, was very common in Argentina (ZAMPONI 2002). However, that conclusion was based on only four specimens of the jellyfish. Still, L. spinosa is abundant in Argentina (Boschi et al. 1992) and the jellyfish is rare near the coast (ZAMPONI 2002), so the young crabs may have colonized all the available jellyfish in that area.

Associated crabs were young and more than $70 \%$ of them were smaller than $15 \mathrm{~mm}$. Several species of fish prey on these crabs (VAz Ferreira 1972, Boschi et al. 1992). Staying inside the medusae when smaller and more vulnerable, due to several molts, may provide an important survival advantage. Also, no smaller crabs were captured as free-living forms on the ocean floor. This data was contrary to PHILLIPs et al. (1969), who found Libinia dubia Milne Edwards, 1834 inside and outside Stomolophus meleagris L. Agassiz, 1862 within the same size range.

The correlation between L. lucerna and L. ferreirae sizes, and the presence of megalops suggests that the crab colonizes the medusa at a post-larval stage. They grow together for some time, until young crabs attain about $3 \mathrm{~cm}$. Then, they fall to the ocean floor and become free-living as a typical adult Brachyura. Similar trends were found by WеYмоuтн (1910 apud Corrington 1927) and by Graham (1989) for Cancer spp.

Associations were more common usually in spring. Population biology of this crab is unknown, but recruitment most likely occurs during the spring, when L. lucerna is abundant and large. Larger medusae are more spacious and more efficient in protecting the crab, and this is supported also by the higher frequency of association with the bigger ones. The greater association frequency in May 2001 was anecdotal and the cause is uncertain.

Libinia ferreirae have been reported in association with the Rhizostomeae $P$. punctata collected in the coast of the state of São Paulo, Brazil (Moreira 1961). In our observations, however, the only occurrence seemed occasional, since several other stranded and living specimens of this medusae were seen and no crabs were found. No other abundant medusae species, including the scyphozoan C. lactea and the cubozoan C. quadrumanus had crabs.

In addition to this study, 16 records on associations between crabs and medusae were found in the literature, including at least seven species of crabs associated with nine species of jellyfish (Tab. I). Although associations between crabs and medusae are apparently not species-specific, three species of Libinia appeared mainly with four Rhizostomeae jellies (eight records). These results agree with this work where $L$. ferreirae was found on Rhizostomeae only, which are usually larger and less harmful medusae, possibly due to the presence of epidermal cnidae only in the oral arms (tentacles are absent in 
Rhizostomeae). Although nothing is known about $L$. ferreirae immunity to nematocysts, it is likely that they are immune or can tolerate their stings,, which may give additional protection, such as demonstrated in the spider crab L. dubia and the jellyfish S. meleagris (SHANKS \& Graham 1988). Cnidae resistance in $L$. ferreirae can also be noted by the high frequncy of sea anemones found on the adults living outside the medusae. This may indicate that the tolerance of cnidae lasts through its entire life cycle and to types of toxins from different taxa of Cnidaria (Scyphozoa and Anthozoa).

With respect to the type of association, we consider it probably only beneficial to the crab (CorRINGTON 1927, VAZ Ferreira 1972, Zamponi 2002). The association could even be harmful to L. lucerna, if the crab feeds on parts of its host tissue, a trend not observed in this study, but reported for $L$. dubia associated with $A$. aurita (Linnaeus, 1758) and $S$. meleagris, respectively by JACHOWSKI (1963) and SHANKS \& Graham (1988).

\section{CONCLUSIONS}

Associations among different taxa are important in community structure and the evolution of ecosystems. The development of the young spider crab L. ferreirae probably is dependent upon the jellyfish L. lucerna that works as a floating nursery area in the studied site.

\section{ACKNOWLEDGEMENTS}

CAPES provided scholarship research for the first author. Dr. Arno Blanksteyn and Dra. Iracema Gomes provided material of 1999 and 2001/2002, separated from their samples. Micheli C. Thomas and Drs Maurício O. Zamponi, Rogério C. Costa and Joel W. Martin provided important literature. Renato G. Rodrigues provided some observations about the association, Ana Carolina Hatschbach revised the English in an early version of the manuscript and Dr. André C. Morandini kindly read and provided constructive criticisms. Two anonymous referees provided useful suggestions.

\section{REFERENCES}

AraI, M.N. 1997. A functional Biology of Scyphozoa. London, Chapman \& Hall, 315p.

Boschi, E.E.; C.E. Fischbach \& M.I. Iorio. 1992. Catálogo ilustrado de los crustáceos estomatópodos y decápodos marinos de Argentina. Frente Maritimo, Montevidéo, 10: 7-94.

BRowne, J.G. \& M.J. KingsFord. 2005. A commensal relationship between the scyphozoan medusae Catostylus mosaicus and the copepod Paramacrochiron maximum. Marine Biology, Berlim, 146: 1157-1168.

Corrington, J.D. 1927. Commensal association of a spider crab and a medusa. Biological Bulletin, Woods Hole, 53: 346-350.

Franc, A. 1994. Classe des Scyphozoaires, p. 596-884. In: P.P. Grassé \& D. Doumenc (Eds). Traité de Zoologie, Anatomie, Systématique, Biologie. Paris, Masson, tome 3, fascicule 2, 1117p.
Graham, W.M. 1989. Long-term association of Cancer sp. crabs with Scyphomedusae in Monterey Bay. V International Conference on Coelenterate Biology, Southampton, 5: 38-39.

GuTSELL, J.S. 1928. The spider crab Libinia dubia and the jellyfish Stomolophus meleagris found associated at Beaufort, North Carolina. Ecology, Washington, 9: 358-359.

JACHOWsкI, R. 1963. Observations on the moon jelly, Aurelia aurita, and the spider crab, Libinia dubia. Chesapeake Science, Solomons, 4 (4): 195.

Martin, J.W. \& H.G. KuCK. 1991. Faunal associates of an undescribed species of Chrysaora (Cnidaria, Scyphozoa) in the Southern California Bight, with notes on unusual occurrence of other warm water species in the area. Bulletin of Southern California Academy of Sciences, Los Angeles, 90 (3): 89-101.

Mayer, A.G. 1910. The medusae of the world. The Scyphomedusae. Washington, Carnegie Institution, vol. 3, p. $499-735$ p.

Melo, G.A S. 1996. Manual de Identificação dos Brachyura (Caranguejos e Siris) do Litoral Brasileiro. São Paulo, Editora Plêiade, 640p.

Mianzan, H. \& P.F.S. Cornelius. 1999. Scyphomedusae and Cubomedusae, p. 513-559. In: D. Boltovsкoy (Ed). South Atlantic Zooplankton. Leiden, SPB Academic Publishing, 1500p.

Moreira, M.G.B.S. 1961. Sobre Mastigias scintillae sp. nov. (Scyphomedusae, Rhizostomeae) das costas do Brasil. Boletim do Instituto Oceanográfico da Universidade de São Paulo, São Paulo, 11 (2): 5-30.

Philuips, P.J.; W.D. Burke \& E.J. Keener. 1969. Observations on the trophic significance of jellyfishes in Mississippi Sound with quantitative data on the associative behavior of small fishes with medusae. Transactions of American Fisheries Society, Bethesda, 4: 703-712.

Pohle, G.; F. Mantelatto; M.L. Negreiros-Fransozo \& A. Fransozo. 1999. Larval Decapoda (Brachyura), p. 1281-1351. In: D. Boltovskoy (Ed). South Atlantic Zooplankton. Leiden, SPB Academic Publishing, 1500p.

Ross, D.M. 1983. Symbiotic Relations, p. 163-212. In: F.J. VERNBERG \& W.B. VernBERg (Eds). The biology of Crustacea Behavior and Ecology. New York, Academic Press, vol. 7, 318p.

Shanks, A.L. \& W.M. Graham. 1988. Chemical defense in a scyphomedusa. Marine Ecology, Progress Series, Oldendorf, 45: 81-86.

VAz Ferreira, C. 1972. Relaciones de convivência entre Libinia spinosa Milne Edwards (Decapoda, Brachyura) y Discomedusae. Boletin de la Sociedad Zoologica del Uruguay, Montevidéo, 2: 64-66.

ZAMPONI, M.O. 2002. The association between medusa Lychnorhiza lucerna (Scyphomedusae, Rhizostomeae) and the decapod Libinia spinosa (Brachyura, Majidae) recorded for the first time in neritic waters of Argentina. Russian Journal of Marine Biology, Vladivostok, 28 (4): 267-269.

Received in 06.IV.2005; accepted in 04.X.2005. 